\title{
BIM Feasibility Study For Housing Refurbishment Projects In The UK
}

Ki Pyung Kim

School of Engineering \& Applied Science,

Aston University, Aston Triangle,

Birmingham, UK

kimkp@aston.ac.uk
Kenneth S. Park

School of Engineering \& Applied

Science, Aston University,

Aston Triangle, Birmingham, UK

s.h.park@aston.ac.uk
DOI 10.5592/otmcj.2013.3.1

Research Paper

\section{Keywords}

Building Information Modelling (BIM), Housing Refurbishment, Technology Adoption
CURRENT EXISTING UK HOUSING STOCK IS RESPONSIBLE FOR $27 \%$ OF UK CO2 EMISSION. REFURBISHING THIS HOUSING STOCK CAN CONTRIBUTE TO THE 80\% CO2 REDUCTION BY 2050 AS A UK GOVERNMENT TARGET. However, there are barriers to refurbish a house due to high initial cost and lack of knowledge and skills in construction sector. To accomplish the $\mathrm{CO}_{2}$ reduction target, BIM should be utilized because BIM is capable of coping with current barriers. Furthermore the UK government mandates public sector to adopt BIM for construction projects from 2016. Hence, this research aims to explore the feasibilities of BIM adoption for housing refurbishment. This research consists of a desk study, web-based questionnaires, and semi-structured interviews. The data search used mostly public statistics and government reports. The target for questionnaire survey was chosen from local authorities, architects and constructors, construction professional organizations, and BIM software developers as a focused group. The web-based questionnaire was comprised of 16 questions, and it was distributed to 100 construction professionals via email. The findings revealed that the BIM adoption for housing refurbishment projects is feasible and timely, although the clients' demand and BIM penetration in the housing sector is low. This research identified that the benefits of BIM should be understood by stakeholders to increase BIM awareness and demand. In addition, BIM education and financial supports were identified as the most critical steps for encouraging BIM adoption. Furthermore, the construction professionals are aware of the benefits of BIM whether they are engaged in BIM or not. 


\section{INTRODUCTION}

The UK government legislated in the Climate Change Act 2008 for an $80 \%$ reduction in $\mathrm{CO}_{2}$ emission by 2050 against 1990 level. This reduction is a challenging target and could be achieved if energy efficiency across all sectors of the UK economy is improved, particularly in the housing sector. Currently, $45 \%$ of total $\mathrm{CO}_{2}$ emission in the UK is generated from the existing buildings. In particular, existing housing stock accounts for $27 \%$ and non-domestic buildings accounts for 18\% (Kelly, 2009). Furthermore, $87 \%$ of the housing which is responsible for current $27 \% \mathrm{CO}_{2}$ emission will still stand in 2050 (Boardman, 2007). In order to achieve the $\mathrm{CO}_{2}$ reduction target, existing housing stock needs to be improved substantially in the energy efficiency (Summerson, 2011; Itard and Meijer, 2008). Although the government committed to increase the number of new homes about 3 million by 2020 (ONS, 2011), it is insufficient to replenish the $87 \%$ housing stock with new build housing. It is because the average replacement rate of the existing housing stock to new homes has been less than $1 \%(50,000)$ per year (Owen, 2011; Construction Products Association, 2010; Power, 2008). It has been estimated that 600,000 houses per each year need to be refurbished from 2012 to achieve the $80 \%$ reduction (BRE, 2010).

\section{The state of housing}

\section{refurbishment in the UK}

Currently, 27 million existing domestic buildings and 2 million existing nondomestic buildings are in need of refurbishment in the UK (Summerson, 2011). Housing refurbishment is a challenging task because domestic buildings have a long life (50 to 100 years), $70 \%$ of housing stock is privately owned (Utley and Shorrock, 2011). Furthermore, there is a great variation in the housing types, years built, construction types and locations in the stock. As shown in Table 1, the $79 \%$ of current housing stock was built before 1980 (DCLG, 2010) when the Code for Sustainable Homes was not mandatory. Consequently, it is most likely that a large amount of housing stock is in poor energy efficiency.

Given the broad variations in the UK housing stock, there is no 'one fits all' solution for housing refurbishment (Jenkins, 2010; Firth and Lomas, 2009). Approaches to refurbishment are categorized into two types: measure approach and whole-house approach. The measure approach usually adopts quick and easy installation of individual component such as cavity wall insulation, loft insulation and double glazing. In contrast, the wholehouse approach is a holistic system change approach integrating various refurbishment options such as the fabric (floors, solid walls and roofs), the services (HVAC, hot water and lighting) and renewable energy systems (PV panel, solar water heating and etc.).

The UK government has initiated a series of government incentive schemes that mainly focus on refurbishment measures with relatively low upfront costs and a short payback period, such as: cavity wall insulation, loft insulation and window replacement. These measures have been increasingly installed due to the economic viability, minimum disruption and opportunities for the government funding as shown in Figure 1 (Palmer and Cooper, 2012 ; Summerson, 2011; Construction Products Association, 2010). However, currently installed measures are capable of achieving only the limited $\mathrm{CO}_{2}$ reduction by 25 to $35 \%$ (Thorpe, 2010; McMullan, 2007). As a result, many researchers share the viewpoint that comprehensive wholehouse refurbishments are required to achieve the reduction target in the housing sector (Reeves, 2009; Killip 2008; Boardman 2007), and the UK government released the whole-house refurbishment strategy to improve the efficiency of individual homes (DECC, 2009). However, there are barriers to carry out the whole-house refurbishment, such as: high initial costs and the fragmented nature of the construction sector.

In order to achieve the $\mathrm{CO}_{2}$ reduction target, the high initial cost should be reduced and the current fragmented practice should be improved to

\begin{tabular}{|l|l|l|l|l|l|}
\hline Built Year & $\mathbf{2 0 0 7}$ & $\mathbf{2 0 0 8}$ & $\mathbf{2 0 0 9}$ & $\mathbf{2 0 1 0}$ & Stock (\%) \\
\hline Pre 1919 & 4,766 & 4,760 & 4,794 & 4,865 & $21.7 \%$ \\
\hline $1919-1944$ & 3,864 & 3,642 & 3,689 & 3,751 & $16.8 \%$ \\
\hline $1945-1964$ & 4,345 & 4,363 & 4,504 & 4,397 & $19.6 \%$ \\
\hline $1965-1980$ & 4,806 & 4,814 & 4,631 & 4,602 & $20.6 \%$ \\
\hline $1981-1990$ & 1,878 & 1,953 & 1,981 & 1,880 & $8.4 \%$ \\
\hline Post 1990 & 2,531 & 2,708 & 2,735 & 2,892 & $12.9 \%$ \\
\hline Total & 22,190 & 22,240 & 22,334 & 22,387 & $100.0 \%$ \\
\hline
\end{tabular}

Table 1. The Number of House and Year Built in England (DCLG, 2007 to 2010) 


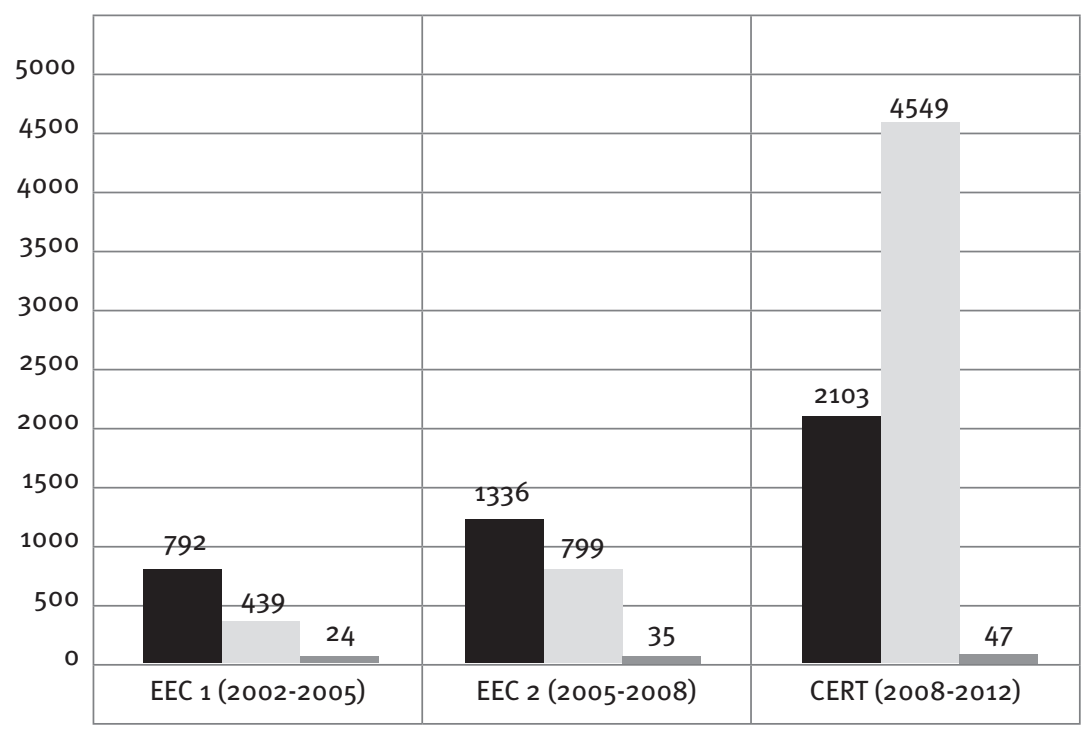

provide proper quality refurbishment outcomes to customers. Recently, Building Information Modeling (BIM) has gained increasing attention from the AECO (architecture, engineering, construction and operation) industry since BIM has capability to cope with various problems facing the construction industry including high construction project cost and environmental issues such as energy performance and $\mathrm{CO}_{2}$ reduction. There are various research works and commercial reports released that reveal the benefit of using BIM (NHBC, 2013; Redmond, 2012; BSI, 2010; Grilo and Jardim-Goncalves, 2010) in the non-domestic building construction. However, limited amount of literature and studies is dedicated to BIM utilization for housing refurbishment. Hence, this research aims to explore the feasibilities of BIM adoption for housing refurbishment, and finally can contribute to increase uptake of whole-house refurbishment in the UK housing sector.

\begin{tabular}{|c|l|}
\hline Viewpoint & Barriers \\
\hline & $\begin{array}{l}\text { Perceived costs exceed perceived benefits } \\
\text { (High capital cost and disruption) }\end{array}$ \\
\hline Clients & Little knowledge about sustainable refurbishment technologies \\
\hline & Little understanding about home occupants' preferences \\
\hline The & Fragmented nature of the construction sector \\
\hline Sector & Lack of skilled construction personnel \\
\hline & Ineffective process to determine refurbishment solution \\
\hline
\end{tabular}

References: Konstantinoua and Knaack, 2013; Davies and Osmani, 2011; Menassa, 2011; Owen, 2011; Thuvander et al., 2012; DECC, 2011; Energy Saving Trust, 2011.

Table 2. Barriers in the whole-house refurbishment
Cavity Wall

Loft

Solid Wall

Figure 1.

Insulation measures installed under EEC and CERT (thousands of households)

\section{Barriers of the whole-house refurbishment}

The most important benefit of the whole-house approach is that house can be refurbished in the sustainable manner with right sequence and using proper construction material. This approach is more expensive and disruptive than measure approach since whole house will be refurbished, however significant energy savings and $\mathrm{CO}_{2}$ reduction can be achieved immediately (Construction Products Association, 2010). Since an existing house is reused, the embodied energy is conserved. The new build generates 50 tonnes of embodied $\mathrm{CO}_{2}$ while the refurbishment generates 15 tonnes (BSHF, 2008). However, the uptake of whole-house approach is low due to the barriers existed in the refurbishment projects as shown in Table 2.

\section{Viewpoint of Clients}

The primary barrier is the high initial cost to adopt whole-house refurbishment (BRE Trust, 2005). According to the DECC customer survey report (2011), the overall annual savings are between $f_{5}$ and $f_{30}$ by adopting loft and cavity wall insulation and window replacement. The amount of energy savings is considered too small to be worthy to invest, and households do not like the disruption during the refurbishment. 
Majority of clients wanted shorter payback period less than ten years (DECC, 2011). Furthermore, without careful design and planning for refurbishment works, additional cost and delay will be occurred due to redesign and reworks (Plimmer et al., 2008).

The secondary barrier is a lack of knowledge about sustainable refurbishment technologies. Majority of households have limited information about refurbishment measures. Due to the limited information, clients have difficulties to identify if the provided refurbishment solution by a construction professional is the best option for them (Owen, 2011). Usually, the housing refurbishment projects are carried out SMEs (small medium enterprises) recommended by word-ofmouth, and even some refurbishment projects are conducted by unskilled and inexperienced contractors (Ranaweera and Prbhu, 2003). As a result, customers have trust issue with the construction professionals, and have conception that they could propose deceitful cost estimation (Killip, 2008).

The tertiary barrier is a lack of understanding about home occupants' preferences. In particular, home occupants have different level of acceptability about refurbishment solutions, and it is as important as the technical feasibility (Loveday et al., 2011). The researchers found out that appealing refurbishment solutions to home occupants could improve customer satisfaction, and increase uptake of refurbishment measures (Klotz, 2011). As a result, when home occupants contacted design or construction professionals, they feel uncomfortable with the provided solutions in terms of cost and refurbishment solution, and even feel that they try to sell unnecessary services (DECC, 2011; Energy Saving Trust, 2011).

\section{Viewpoint of the Construction Sector}

It has been long been emphasized that the fragmented nature of the construction sector needs to be improved for better quality of project outcome and satisfaction of clients (Rysanek and Choudhary; 2013; Klotz, 2011). In particular, ineffective decision making at the early design stage will lead significant impacts on time and cost of a project, and generates reworks (Basbagill et al., 2013; Konstantinoua and Knaack, 2013; Schlueter and Thesseling, 2009). Thus, in order to provide a reliable refurbishment solution to customers, diverse information regarding refurbishment measures should be communicated and coordinated amongst stakeholders from the early design stage.

Secondly, there is a lack of skilled personnel in the construction sector ( $\mathrm{CIOB}$, 2011). In order to provide an affordable and quality refurbishment solution to customers, the solution should be financially and technically feasible. In addition to these two aspects, the environmental feasibility, such as energy performance and $\mathrm{CO}_{2}$ reduction, should be integrated. However, currently there are not enough skilled and experienced personnel to make a right decision about sustainable refurbishment solutions (Forum for the future, 2012). Abovementioned, this situation results in mistrust between clients and the construction professionals.

Finally, the current process is deemed to fail to support effective decisionmaking, since there is no standardized process for refurbishment projects (Burton, 2012; Leblanc et al., 2010; Doran et al., 2009). Since the wholehouse refurbishment considers all potential refurbishment measures, the process must support effective decisionmaking to provide technically buildable, financially feasible and environmentally responsible refurbishment solution.

Consequently, the reduction of high initial costs and collaboration amongst project participants are essential to promote whole-house refurbishment. For this purpose, the BIM is required to integrate diverse information from the early design phase, and facilitate collaboration and coordination amongst project participants.
BIM for housing refurbishment project

Recently, the needs of customers for buildings have become diverse, and the designs of buildings have become more irregular and bespoke in its shapes. In addition, sustainability issues, such as energy performance and $\mathrm{CO}_{2}$ reduction, became one of major considerations in the housing refurbishment project. As a result, the current $2 \mathrm{D}$ system cannot handle the complicated design, and manage larger size of construction information through the life cycle of a project. Furthermore, a proper management system is necessitated to integrate the current fragmented practice, and minimize data conflicts and unnecessary reworks.

As a response to the current problems, a large amount of researches to explore proper information and communication technologies (ICT) has carried out. As a result, BIM is recognized as a new ICT to manage the fragmented practice, and improve productivity in the construction industry. Consequently, BIM is currently increasingly adopted by the AECO industry. $B I M$ is an information system to integrate and manage various construction information throughout a construction project life cycle based on $3 \mathrm{D}$ digital representation, and a tool to support project participants achieving a project goal in collaborative manner.

There are three major benefits commonly addressed amongst researchers and practitioners such as: a) Design Optimization, b) Efficiency Improvement (Effective Project Information Management) and c) Sustainability Enhancement (Redmond, 2012; BSI, 2010; Grilo and Jardim-Goncalves, 2010; Sacks et al., 2010). According to the government report (Government Construction Client Group, 2011), the current measured benefit of BIM is about $38 \%$ reduction of total construction project cost, and $19 \%$ to $40 \%$ cost reduction is expected from design stage alone. If 
BIM is properly adopted in the housing refurbishment projects, the high initial cost could be minimized, and the fragmented practice can be improved (BRE Trust, 2005). According to HM government (2012), BIM has potentials to be used for refurbishment projects.

The current status of BIM penetration in the UK housing sector is limited as shown in Figure 2 (NHBC, 2013). According to the NHBC foundation (2013), major house builders in the UK consider the BIM adoption for housing projects are not relevant to current construction practices. This research provides a snapshot about current status of BIM penetration in the housing sector, although this survey mainly focused on the new build housing projects.

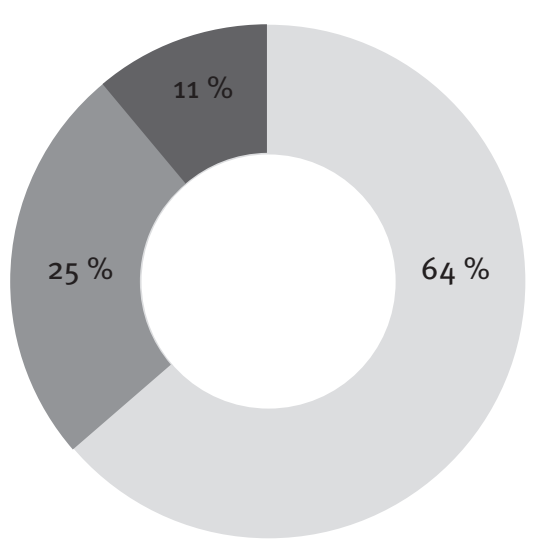

Not heard of BIM

Using BIM

Aware of BIM but not using

Figure 2. BIM Adoption in the UK Housing Industry (NHBC, 2013)

There were academic efforts to implement BIM in the housing sector, although the studies are mainly carried out in the new building housing projects. Sebastian et al. (2009) applied BIM for small scale housing development project. Through this research, it was identified that there were benefits and limitations in BIM adoption in the housing sector. BIM facilitated proactive early collaboration amongst project participants. In particular, the earlier engagement of constructors in the design phase added value to the more accurate informed decision on cost estimation and selection of construction materials. However, there are limitations due to data exchanges between different software systems, and the current legal contract issues.

Chung et al. (2013) implemented BIM for a 34 storey domestic buildings. Researchers explored full potentials of BIM such as $3 \mathrm{D}, 4 \mathrm{D}$ and ${ }_{5} \mathrm{D}$ BIM. As a result, It was revealed that BIM can rendered various benefits such as: 3D BIM for constructability and sustainability check, 4D BIM for better risk management by virtual schedule planning for construction works and equipment operation. However, the benefit of 5 D BIM was not clearly identified since there is a lack of standardized method for quantity measurement in BIM environment.

Through the literature review, it is identified that the potential BIM use for housing refurbishment has been rarely researched (Allen Consulting Group, 2010; Arayici et al., 2011). In spite of the various advantages of BIM, few researches were carried out to explore possibility of adopting BIM for housing refurbishment projects. To fill this research gap, this exploratory research was carried out to explore the feasibility of BIM utilization in the housing refurbishment projects.

\section{Methodology}

This research consists of a desk study, web-based questionnaires, and semistructured interviews. In order to collect various viewpoints of the construction professionals, the target for questionnaire survey was chosen from local authorities, architects and constructors, construction professional organizations, and BIM software developers as a focused group. Targeted 100 professionals were identified via construction professionals organization websites such as Chartered Institute of Building (CIOB), Royal Institution of Chartered Surveyors (RICS), Royal Institution of British Architects (RIBA), Building Research Establishment (BRE) and personal contact information retrieved from ICE retrofit solutions conference 2011 and 2012.

The web-based questionnaire was comprised of 16 questions designed to explore the following four key information about BIM; a) awareness and current status, b) benefits, c) challenges, and d) feasibility of BIM use for housing refurbishment project. The questions consisted of multiple choice and rating questions that obtain facts and inquire personal opinions as a subject matter expert. After the completion of the webbased questionnaire survey, the semistructured interviews were conducted with those who addressed their interest about BIM for the housing sector. Due to the geographical distance, the semistructured interviews were conducted via web-based conference system such as Skype.

\section{Research Results and Discussion}

Total 100 professionals were selected for the questionnaire survey, and the response rate was $51 \%$ ( 51 out of 100 ). The average experience of respondents was 18 years, and 60\% (31 respondents) has more than 20 years of experience in the housing sector. The respondents' profile is as shown in Table 3.

\section{Awareness and Current Status of BIM}

Respondents were asked to indicate current use of BIM and awareness of UK BIM strategy. Most professionals ( $81 \%$ of respondents) are aware of UK BIM strategy from Level o to Level 3. In contrast with professionals, it was revealed that their clients' demand of BIM is low (61\%) as shown in Figure 3. 


\begin{tabular}{|c|c|c|c|c|c|c|c|c|c|c|c|c|c|}
\hline AT & QS & PC & PM & BC & PB & BS & CE & SE & FM & SC & $\mathbf{T}_{1}$ & SE & Total \\
\hline 19 & 8 & 6 & 6 & 6 & 4 & 4 & 4 & 4 & 4 & 3 & 2 & 2 & 51 \\
\hline \multicolumn{14}{|c|}{ *Reference } \\
\hline & AT & & \multicolumn{4}{|c|}{ Architect } & & \multicolumn{2}{|l|}{ CE } & \multicolumn{4}{|c|}{ Civil Engineer } \\
\hline & QS & & \multicolumn{4}{|c|}{ Quantity Surveyor } & & SE & & \multicolumn{4}{|c|}{ Structure Engineer } \\
\hline & PC & & \multicolumn{4}{|c|}{ Private Client } & & \multicolumn{2}{|l|}{ FM } & \multicolumn{4}{|c|}{ Facilities Management } \\
\hline & PM & & \multicolumn{4}{|c|}{ Project Management } & & \multicolumn{2}{|l|}{ SC } & \multicolumn{4}{|c|}{ Specialist Contractor } \\
\hline & $\mathrm{BC}$ & & \multicolumn{4}{|c|}{ BIM Consultant } & & \multicolumn{2}{|l|}{$\mathrm{T} 1$} & \multicolumn{4}{|c|}{ Tier 1 Contractor } \\
\hline & PB & & \multicolumn{4}{|c|}{ Public Client } & & \multicolumn{2}{|l|}{ SE } & \multicolumn{4}{|c|}{ Service Engineer } \\
\hline & BS & & \multicolumn{4}{|c|}{ Building Surveyor } & & & & & & & \\
\hline
\end{tabular}

Table 3. Respondents Profile (Number of Respondents)

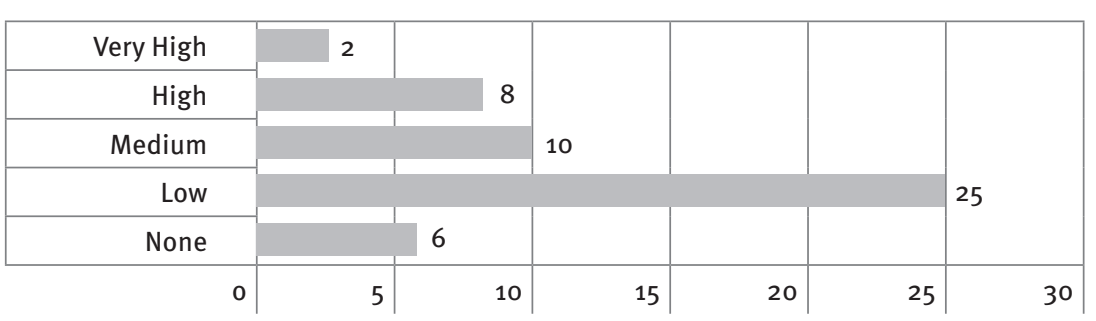

Figure 3. Awareness and Demand of BIM, Clients' Standpoint *Note: $\mathrm{x}$-axis is the number of respondents

\begin{tabular}{|c|c|c|c|c|}
\hline Use for small size projects & 1 & & & \\
\hline Plan to adopt & 4 & & & \\
\hline Other & & 8 & & \\
\hline Just adopt and start to use & & & 10 & \\
\hline Use for every project & & & 12 & \\
\hline Not use & & & & 16 \\
\hline 0 & 5 & 10 & 15 & 20 \\
\hline
\end{tabular}

Figure 4. Current Status of BIM Use

*Note: $\mathrm{x}$-axis is the number of respondents

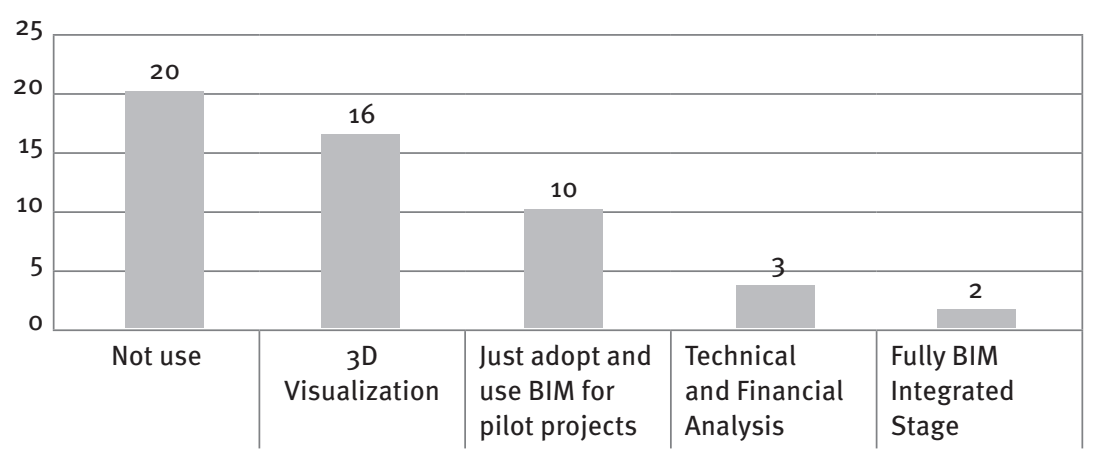

Figure 5. Purpose of BIM Use

*Note: $y$-axis is the number of respondents
Respondents were asked to indicate the current use of BIM, and the result was revealed as shown in Figure 4. About $60 \%$ of respondents indicated that they are not engaged to use BIM, and this result showed very similar percentage with the outcome of NHBC survey (2013) which is $64 \%$ non-BIM use. 8 respondents indicated that they belonged to the other since they are BIM software developer (2 respondents) and BIM education and consultants (6 respondents). 12 respondents who indicated that they use BIM for every project were consisted of 8 architect, 2 civil engineer and 2 structure engineer, and it could be assumed that architect are the dominant user for BIM at the design phase of a project.

The semi-structured interviews were conducted after analysing this data, and interviewees addressed the challenges of BIM adoption. Mainly, they mentioned about motivation of clients and their organizations. Aforementioned, the current clients' demand for BIM is low, and in addition to this, there is resistance in their organization to embrace practice change by adopting BIM for their projects.

Finally, respondents were asked to indicate what kind of functions they use BIM for, and the result was revealed as shown Figure 5.

Except those who are not engaged in BIM and just adopt, most respondents 


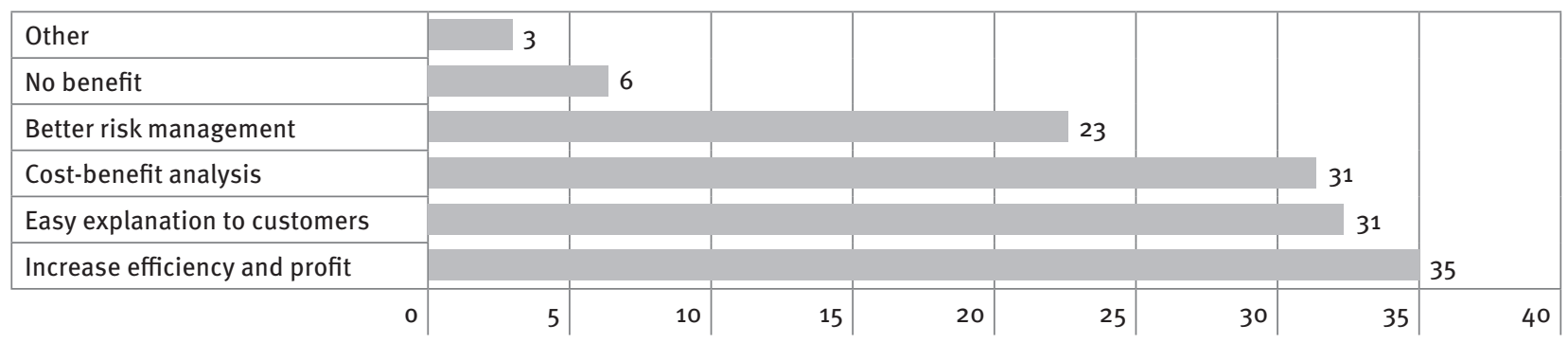

Figure 6. Benefits of BIM in housing refurbishment

*Note: $x$-axis is the number of respondents

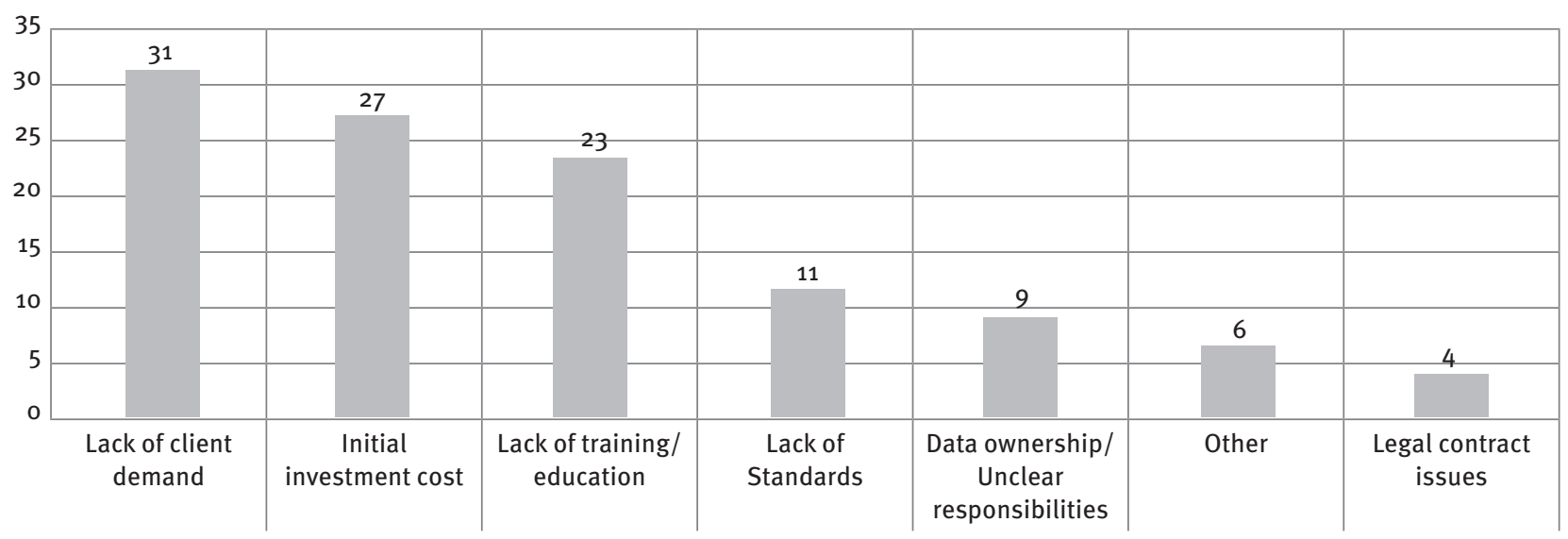

Figure 7. Challenges of BIM adoption in housing refurbishment

*Note: $y$-axis is the number of respondents

(16 professionals) used BIM for 3D visualization to communicate with project team and present a design in 3D manner. Those who indicated the technical and financial analysis utilized BIM for energy performance simulation and life cycle cost calculation for refurbishment measures and construction materials. Interestingly, there are two respondents indicated that they utilized full extend of BIM up to $5 \mathrm{D}$ cost management. However, the validity of these answers are questionable since the definition of BIM is contentious amongst practitioners and researchers. Furthermore, two respondents are BIM consultants and the answers could reflect their own viewpoints.

The semi-structured interviews were followed to obtain additional insights about current purpose of BIM use. First of all, interviewees addressed the issue of dataset for calculating life cycle cost and $\mathrm{CO}_{2}$. Difficulty to obtain reliable data source about construction materials were addressed, and necessity of BIM library that provide quick and accurate standard model for refurbishment measures. Finally, interviewees shared the same viewpoint about fully integrated BIM environment that BIM requires cultural and organizational changes. They agreed that BIM adoption is not just switching or learning new software, but adopting a facilitator for changes of process and culture in the construction industry (Succar, 2009; Hannele et al., 2012).

\section{Benefits of BIM in housing} refurbishment

Respondents were asked to indicate benefits of BIM, and the result was as shown in Figure 6. This question allowed multiple choices.
Respondents were keenly aware of the benefits of BIM even if they are not engaged BIM currently. They mainly addressed the $3 \mathrm{D}$ modelling function that enables them to explain complicated design effectively and easily in $3 \mathrm{D}$ manner. As a result, customers and project team understand better about the refurbishment measures and address their opinion more clearly. Furthermore, BIM has capability to perform comparative cost-benefit analysis between various refurbishment measures. According to respondents, this comparative analysis can be done much quickly and efficiently than 2D base system. Six respondents who selected no benefits addressed that they do not know the benefit of BIM since they are not using BIM currently. There are three responses on others that include better asset management, effective management on bespoke design. 
Challenges of BIM adoption in housing refurbishment

Respondents were asked to indicate challenges of BIM adoption, and the result was as shown in Figure 7. This question allowed multiple choices.

The result revealed that initial investment for adopting BIM and lack of client demand are the most challenging issues. Lack of training and education how to use BIM is followed. As it was revealed in Figure 3, current demand and awareness of BIM amongst clients are low, and respondents are reluctant to invest on BIM although they are keenly aware of benefits of BIM. In addition, since BIM facilitate the collaborative working environment, the ownership of BIM data is issues, and a lack of standard of BIM for housing refurbishment project make unclear roles and responsibilities amongst project team. There are other challenges addressed such as a lack of incentive to use BIM. Quote from the questionnaire survey indicated that "There is minimal additional incentives in this type of work and much higher costs in using BIM." In addition, difficulty to transfer housing condition survey result to BIM and a lack of quality BIM families (BIM data/content) are addressed.

Feasibility of BIM adoption in housing refurbishment

Respondents were asked to indicate the feasibility of BIM adoption

in terms of timing, and asked to address the reason for the answers. The result was as shown in Figure 8.

$57 \%$ (29 respondents) indicated that the BIM adoption is timely, and $22 \%$ indicated too early for the adoption. As respondents as construction professionals, they see the benefits and challenges of BIM. 16 respondents who indicated early or too early mentioned that the housing sector has its uniqueness of housing stock, and it requires lots of work to adopt BIM such as establishment of BIM standard and

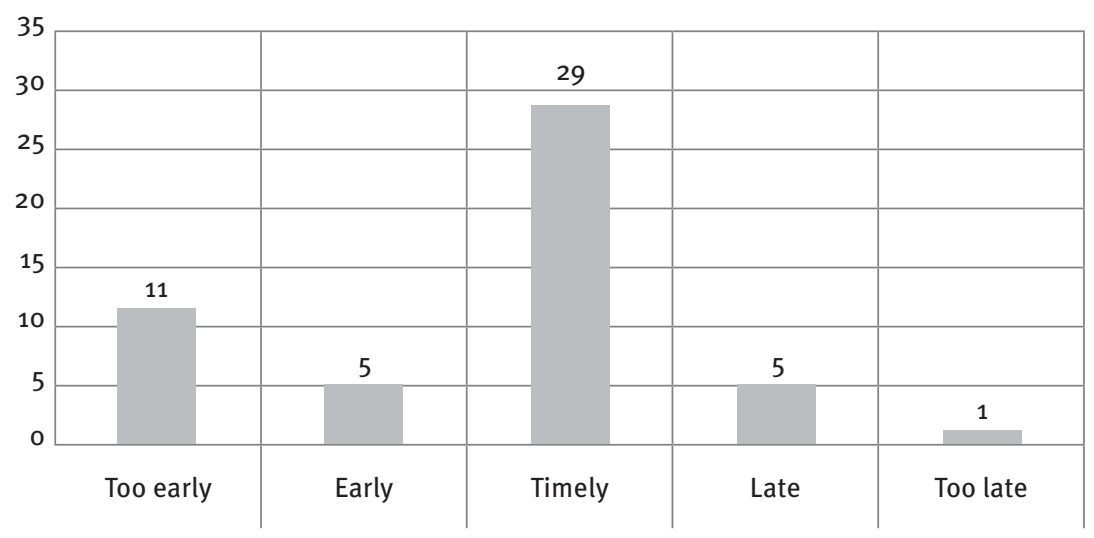

Figure 8. Feasibility of BIM adoption in housing refurbishment

*Note: $y$-axis is the number of respondents

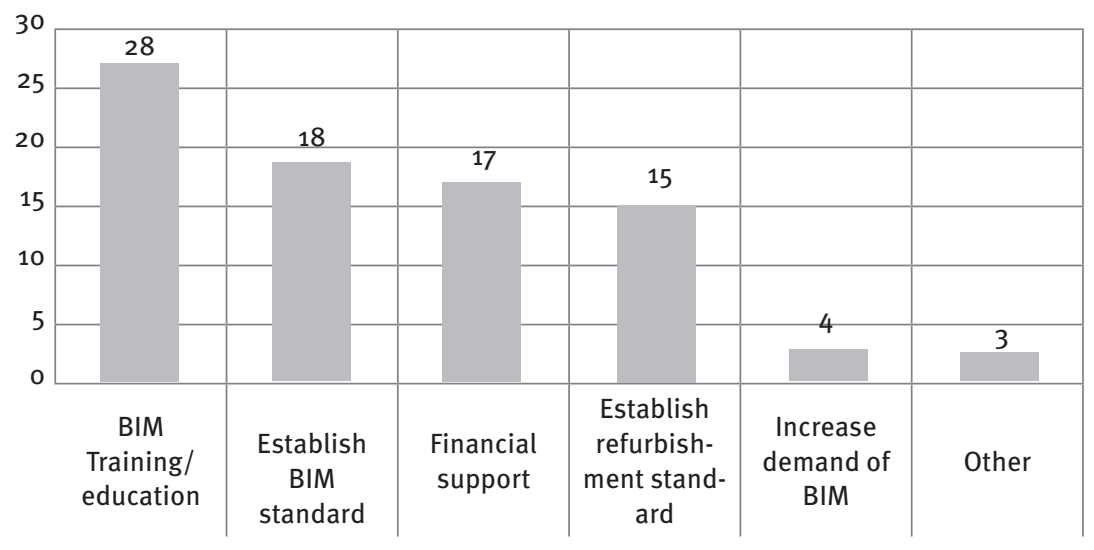

Figure 9. Critical steps for BIM adoption in housing refurbishment

*Note: $y$-axis is the number of respondents

process, proper legal amendments in contracts and proper incentives. In order to identify the critical steps for the housing sector to embrace BIM, Respondents were asked to indicate what the critical steps are to be undertaken. The result of the question was as shown in Figure 9. This question allowed multiple choices.

Respondents addressed that BIM training and education is the most critical to increase BIM adoption in the housing sector. They indicated that clients and organization should clearly understand the benefits of BIM first, then the demands of BIM will be increased. In addition, the need for BIM standard and financial support for initial BIM adoption was revealed. Increase demand of BIM received four responses, and this could be occurred naturally if the BIM education is supplied enough to the housing sector.

Through the four semi-structured interviews, it was revealed that the housing sector was relatively insensitive to BIM adoption. Interviewees addressed that housing is deeply related with households' lifestyle, and home occupants are not interested in complicated housing refurbishment with long payback period. They are more interested in quick and easy installation such as windows replacement and voltage regulators. One interviewees mentioned that some of households do not like the government funding scheme such as Green Deal. In addition, there is no financial incentives or rewards when they use BIM for housing refurbishment projects. As a result, the housing sector is reluctant to adopt BIM actively. 


\section{Research Limitations}

This research attempted to explore the feasibility of BIM adoption for wholehouse refurbishment projects. First of all, it was challenging to come up with proper interviewees list, since current BIM penetration in the housing refurbishment business is very low. Secondly, the limited numbers of faceto-face interviews were conducted since geographical locations for interviewees were widely scattered in the UK. Furthermore, many interviewees were reluctant to accept the request for interview since they regarded themselves as not BIM experts.

\section{Conclusions}

This research was conducted to explore main area of concerns to adopt BIM for housing refurbishment projects such as; a)current status of BIM, b)benefits and challenges of BIM adoption, and c) feasibility of BIM use for housing refurbishment project. The findings revealed that the BIM adoption for housing refurbishment projects is feasible and timely, although the clients' demand and BIM penetration in the housing sector is low. In order to encourage adoption, BIM education/training and financial supports are revealed as the most critical steps needed to be undertaken. This research identified that the benefits of BIM adoption should be clearly understood by clients and project team to increase BIM awareness and demand. Furthermore, the construction professionals are aware of the benefits of BIM whether they are engaged in BIM or not. Hence, the BIM adoption for housing refurbishment project is feasible, and the use of BIM should provide a solution to the identified barriers for wholehouse refurbishment by minimizing project costs and supporting informed decision-making process. This research is expected to contribute insights to the housing sector and the UK government to tackle potential future issues for adopting BIM in housing sector since major barriers and critical steps for BIM adoption are revealed. Future research should explore potentials to establish BIM standard/process for housing refurbishment project based on this study.

\section{Reference}

Allen Consulting Group (2010), Productivity in the buildings network: assessing the impacts of building information models, Report to the Built Environment Innovation and Industry Council, Sydney.

Arayici, Y., Coates, P., Koskela, L., Kagioglou, M., Usher, C., O’Reilly, K. (2011) “Technology adoption in the BIM implementation for lean architectural practice", Automation in Construction, Vol. 20 No. 2, pp. 189-195.

Basbagill, J., Flager, F., Lepech, M., Fischer, M. (2013), “Application of life-cycle assessment to early stage building design for reduced embodied environmental impacts", Building and Environment, Vol. 60 (2013), pp. 81-92.

Boardman, B., Darby, S., Killip, G., Hinnells, M., Jardine,C.N., Palmer, J., Sinden, G. (2005), $40 \%$ House, Environmental Change Institute, Oxford, UK.

Boardman, B (2007), Home Truths: A Low-Carbon Strategy to Reduce UK Housing Emission by $80 \%$ by 2050 . Environmental Change Institute, Oxford, UK.

BRE Trust (2005), Putting a price on sustainability, BRE Trust, Watford, UK.

BRE (2010), Sustainable Housing Refurbishment: An update on current guidance and sources of information, BRE, Watford, UK.

BSI (2010), Constructing the Business Case: Building Information Modelling, British Standards Institution and BuildingSMART UK, London and Surrey, UK.

BSHF (2008), "New Tricks with Old Bricks", available at: http://www.bshf.org/ published-information/publication. cfm?thePubID=3DE7278E-15C5-F4Co99E86A547EB36D44 (accessed 8 October 2013).

Burton, S. (2012), Handbook of Sustainable Refurbishment-Housing, Earthscan, Abingdon, UK.

Chung, K.W.L., Mak, S.K.D., Ho, K.K.A. (2013), "Application of building information modelling (BIM) in public housing development in Hong Kong", Proceeding of the HKU-HKHA International Conference 2013, Hong Kong, May, 2013, pp. 51-60.
Haymaker, J., Fischer, M., 2001. Challenges and Benefits of $4 \mathrm{D}$ Modeling of the Walt Disney Concert Hall Project. CIFE Working Paper \#64. Stanford University ([online] Available from: http://cife.stanford.edu/online.publications/ WP064.pdf [accessed January 5th 2011]).

CIOB (2011), A report exploring skills in the UK Construction Industry, Chartered Institute of Building, Berkshire, UK

Construction Products Association (2010),

"An introduction to low carbon domestic refurbishment", available at: http://www. barbourproductsearch.info/CPA-Low-CarbonDomestic-Refurbishment-fileo17103.pdf (accessed 8 October 2013).

Davies, P. and Osmani, M. (2011), “Low carbon housing refurbishment challenges and incentives: Architects' perspectives", Building and Environment, Vol. 46 (2011), pp. 1691-1698.

DCLG - Department for Communities and Local Government (2010), “English Housing Survey Housing Stock Summary Statistics 2010", available at: http://www.communities gov.uk/housing/housingresearch/ housingsurveys/englishhousingsurvey/ ehspublications/ (accessed 8 October 2013).

DECC (2009), Heat and Energy Saving Strategy, Consultation-Department of Energy and Climate Change, London, UK

DECC - Department of Energy and Climate Change (2011), "Consumer Needs and Wants for the Green Deal”, available at: http://www.decc. gov.uk/assets/decc/11/consultation/greendeal/3505-green-deal-consumer-needswants.pdf (accessed 8 October 2013).

Doran, D., Douglas, J., Pratley, R. (2009), Refurbishment and Repair in Construction, Whittles Publishing, Boca Raton, FL.

EST (2011), Trigger points: a convenient truth, Promoting energy efficiency in the home, Energy Saving Trust, London, UK.

Firth, S.K. and Lomas, K.J. (2009), “Investigating $\mathrm{CO}_{2}$ Emission Reductions in Existing Urban Housing using a Community Domestic Energy Model", 11th International IBPSA Conference, Glasgow, Scotland, July, pp. 2098-2105

Forum for the future (2012), "Retro and Fit - Taking energy efficiency in buildings to scale", available at: http://www. forumforthefuture.org/sites/default/files/ images/GreenFutures/Retro_Fit/Retro\%20 \%26\%2oFit.pdf (accessed 8 October 2013). 
Government Construction Client Group (2011),

"Strategy Paper for the Government

Construction Client Group from the BIM

Industry Working Group”, available at

http://www.bimtaskgroup.org/wp-content/

uploads/2012/03/BIS-BIM-strategy-Report.

pdf (accessed 8 October 2013).

Grilo, A., Jardim-Goncalves, R. (2010), “Value proposition on interoperability of BIM and collaborative working environments", Automation in Construction, Vol. 19 No. 5, pp. 522-530.

Hannele, K., Reijo, M., Tarja, M., Sami, P., Jenni, K., Teija, R. (2012), “Expanding uses of building information modeling in life-cycle construction projects", Work, Vol. 41 No. 1 , pp. 114-119, DOI: 10.3233/WOR-2012-0144114, IOS Press.

Hooper, M. and Ekholm, A. (2010), “A Pilot Study: Towards BIM Integration - An Analysis of Design Information Exchange \& Coordination", Proceedings of the CIB W78 2010: 27th International Conference -Cairo, Egypt, 16-18 November.

Itard, L. and Meijer, F. (2008), Towards a Sustainable Northern European Housing Stock: figures, facts and future, Delft University Press, Amsterdam, Netherlands.

Jenkins, D.P. (2010), “The value of retrofitting carbon - saving measures into fuel poor social housing", Energy Policy, Vol. 38 No. 2, pp. 832-839.

Kelly, M.J. (2009), "Retrofitting the existing UK building stock", Building Research \& Information, Vol. 37 No. 2, pp. 196-200.

Killip, G. (2008), Building a Greener Britain; transforming the UK's existing housing stock, Federation of Master Builders, London, UK.

Klotz, L. (2011), “Cognitive biases in energy decisions during the planning, design, and construction of commercial buildings in the United States: an analytical framework and research needs”, Energy Efficiency, Vol. 4 (2011), pp. 271-284.

Konstantinoua, T., Knaack, U., (2013), “An approach to integrate energy efficiency upgrade into refurbishment design process, applied in two case-study buildings in Northern European climate", Energy and Buildings, Vol. 59 No. 2013, pp. 301-309.

Leblanc, H., Nitithamyong, P., Thomson, C. (2010), “Developing a knowledge management framework to promote sustainable social housing refurbishment practices", Proceedings of 26th Annual ARCOM Conference, 6-8 September 2010 , Leeds, UK, Association of Researchers in Construction Management, pp. 819-828.

Loveday, D., Vadodaria, K., Haines, V., Hewitt, N., Hyde, T., Griffiths, P., Critoph, B., Eames, P., Banfill, P., Gillott, M., Darlington, R., Hall, M., Tsang, E. (2011), “Refurbishing the UK's 'hard to treat' dwelling stock: Understanding challenges and constraints the work of Project CALEBRE" CIBSE Technical Symposium, DeMontfort University, Leicester, UK, September 2011, pp. 1-13.

McMullan, R. (2007), Environmental science in building, Palgrave Macmillan, Basingstoke, UK.

Menassa, C.C. (2011), “Evaluating sustainable retrofits in existing buildings under uncertainty", Energy and Buildings, Vol. 43 (2011), pp. 3576-3583.

NHBC (2013), Building Information Modelling - An introduction for house builders, NHBC Foundation, Milton Keynes, UK

ONS (2011), UK Population Projected to reach 70 million by mid-2027, Office of National Statistics, available at: http://www.ons. gov.uk/ons/dcp171780_240701.pdf (accessed 8 October 2013).

Owen, G. (2011), “It's not just about the money: taking the hassle out of energy saving", available at: http://www.sustainabilityfirst. org.uk/docs/2011/taking\%2othe\%20 hassle $\% 200 u t \% 200 f \% 20 e n e r g y \% 20$ saving\%20March\%202011.pdf (accessed 8 October 2013).

Palmer, J. and Cooper, I. (2012), "United Kingdom housing energy fact file", available at: https://www.gov.uk/government/ uploads/system/uploads/attachment_data/ file/201167/uk_housing_fact_file_2012.pdf (accessed 8 October 2013).

Plimmer, F., Pottinger, G., Harris, S., Waters, M. and Pocock, Y. (2008), Knock it down or do it up? Sustainable house building: New build and refurbishment in the Sustainable Communities Plan, BRE, Watford, UK.

Power, A. (2008), “Does demolition or refurbishment of old and inefficient homes help to increase our environmental, social and economic viability?", Energy Policy, Vol. 36 No. 2, pp. $4487-4501$.

Ranaweera, C. and Prbhu, J. (2003), “On the relative importance of customer satisfaction andtrust as determinants of customer retention and positiveword of mouth", Journal of Targeting, Measurement and Analysis for Marketing, Vol. 12 No. 1, pp. 82-9o.

Reeves, A. (2009), “Achieving deep carbon emission reductions in existing social housing: the case of Peabody", Ph.D thesis, De Montfort University, September.

Redmond, A., Hore, A., Alshawi, M., West, R. (2012), "Exploring how information exchanges can be enhanced through Cloud BIM", Automation in Construction Vol. 24 (2012), pp. 175-183.

Rysanek, A.M. and Choudhary, R. (2013), "Optimum building energy retrofits under technical and economic uncertainty", Energy and Buildings, Vol. 57 (2013), pp. 324-337.

Sacks, R., Kaner, I., Eastman, C., Jeong, Y. (2010), “The Rosewood experiment - building information modeling and interoperability for architectural precast facades", Automation in Construction, Vol. 19 (4), pp. 419-432.

Schlueter, A. and Thesseling, F. (2009), "Building information model based energy/exergy performance assessment in early designs stages”, Automation in Construction, Vol. 18 No. 2, pp. $153-63$

Succar, B. (2009), "Building information modelling framework: a research and delivery foundation for industry stakeholders", Automation in Construction, Vol. 18 No. 3, pp. 357-375.

Summerson, G.M. (2011), “Lessons learnt from piloting BREEAM Domestic Refurbishment”, available at: http://www.breeam.org/ filelibrary/breeam\%2orefurb/cibse_ technical_symposium_gavin_summerson_ Paper_102.pdf (accessed 8 October 2013).

Sustainable Development Commission (2006), Stock Take: Delivering improvements in existing housing, Sustainable Development Commission, London, UK.

Thorpe, D. (2010), Sustainable Home Refurbishment, Earthscan, London, UK.

Thuvander, L., Femenías, P., Mjörnell, K., Meiling, P. (2012), “Unveiling the Process of Sustainable Renovation”, Sustainability 2012, Vol. 4 No. 6, pp. 1188-1213.

UK Green Building Council (2008), Low Carbon Existing Homes, Green Building Council, London, UK.

Utley, J.I. and Shorrock, L.D. (2011), “Domestic energy fact file 2011", available at: http://www. decc.gov.uk/assets/decc/11/stats/climatechange/3224-great-britains-housing-energyfact-file-2011.pdf (accessed 8 October 2013). 